\title{
Engineering Education for Sustainable Development and Global Citizenship: A Course-level Implementation Case in Hong Kong
}

\section{Dr. Rosanna Yuen-Yan Chan, Chinese University of Hong Kong}

Rosanna Yuen-Yan Chan is adjunct assistant professor in the Department of Information Engineering, the Chinese University of Hong Kong. She possesses a dual background in engineering and educational psychology. She founded the IEEE Education Society Hong Kong Chapter and is the Founding Chair. Rosanna is currently a Member-at-Large of the Board of Governors of the IEEE Education Society and a Vice Chair of the IEEE Hong Kong SIG in Humanitarian Technology.

\section{Prof. Cecilia KY Chan, University of Hong Kong}

Dr. Cecilia Chan is the Head of Professional Development and Associate Professor in the Centre for the Enhancement of Teaching and Learning at the University of Hong Kong. She has conducted research on topics such as the development and assessment of generic competencies, assessment and engineering education. Cecilia holds a PhD in Engineering from Trinity College, a postgraduate diploma and a MA in Higher Education. She also held a Fellowship from King's College London. Dr. Chan has involved in over 40 research/project grants worldwide. Please see Teaching and Learning Enhancement and Research Group (TLERG): http://tlerg.cetl.hku.hk/

\section{Mr. Mehrdad Tahernia, Chinese University of Hong Kong}

Mehrdad Tahernia was born in Urmia, Iran, in 1988. He received the B.S. degree in electrical engineering and M.S. in communication systems from Shiraz University, Shiraz, Iran and the Sharif University of Technology, Tehran, Iran, respectively. He is now a postgraduate student and teaching assistant at Department of Information Engineering, CUHK.

\section{Mr. Jiaxin Liang, Chinese University of Hong Kong}

Jiaxin Liang received the B.E. degree from the Chinese University of Hong Kong, Hong Kong, in 2015, where he is currently working toward the Ph.D. degree in the Department of Information Engineering. His research interests include wireless communications, multiple access networks, and software-defined radios.

\section{Mr. Qi Cao, Chinese University of Hong Kong}

Qi Cao is a postgraduate student and teaching assistant at Department of Information Engineering, CUHK. 


\section{Engineering Education for Sustainable Development and Global Citizenship: A Course-Level Implementation Case in Hong Kong}

\section{Introduction}

Advancements in technology have transformed modern society. However, new global challenges and emerging issues have arisen alongside technological advancement. These include (but are not limited to) climate change mitigation and adaptation, cyber attacks, and inequalities in health, education, and infrastructure [1].

On 30 December 2015, The United Nations (UN) announced a set of 17 Sustainable Development Goals (SDGs) in its policy document, "Transforming our world: the 2030 Agenda for Sustainable Development" [2]. The SDGs attempt to address and solve global challenges crucial for the survival of humanity. They are universal, transformative, and canvass a range of immense global challenges and goals such as ending poverty and hunger, and the achievement of gender equality. Governments and multinational organizations worldwide have announced and commenced joint endeavors to achieve sustainable development and equitable life on earth for all.

Engineering educators have been asked to take a leading role in ensuring that engineering graduates have the attitude and competencies to apply and contribute professional engineering knowledge for achieving the SDGs [3]. We respond to the call by introducing elements of sustainable development and global citizenship into a major elective course in the Information Engineering curriculum.

\section{Our contribution and significance}

The current work is amongst the early efforts in integrating the achievement of SDGs into the formal undergraduate engineering curriculum. In this paper, we present the corresponding pedagogical design, implementation, and evaluation in a regular undergraduate course offered in Hong Kong. The course aims to introduce to students a wide range of concepts and techniques related to social media analytics and human information interactions. We adopt pedagogical strategies in design thinking to foster engineering student's ability to think critically from multiple perspectives, to be stringent in their application of ethical standards, and to be creative and innovative. Our implementation case study demonstrates how to contextualize and operationalize design thinking at regular course level to facilitate the development of global citizenship in engineering students. We hope this work has answered the vital question of "what can engineering educators do for sustainable development?" and prompt further discussion on engineering education for sustainable development.

\section{Background and Literature Review}

\section{Engineering education for sustainable development}

Engineers are entrusted by the public to apply their professional knowledge and skills to innovate, design and implement solutions for societal needs. It is therefore critically important for 
engineering students to recognize the impact of engineering solutions in relation to industry, society, and the environment in both local and global contexts. Sustainable development refers to "development that meets the needs of the present without compromising the ability of future generations to meet their own needs" [4]. It embraces two major concepts (Ch.2):

1. The needs and in particular, the essential needs of the world's poor such as food, shelter, and jobs; and

2. The limitations imposed by technology and social development on the environment's ability to meet present and future needs.

Over the past two decades, sustainable development and sustainability have played and increasingly important role in engineering education [5]. This increase is achieved by introducing sustainability related criteria in engineering accreditation guidelines and requirements [6]. However, existing engineering curricula are still in their early attempts in implementing sustainability concepts into their corresponding programs and courses (see e.g. [7]).

\section{Engineering epistemology and sustainability competencies}

Engineering knowledge addresses all three intellectual states distinguishes by Aristotle in Nicomachean Ethics [8], namely scientific knowledge (epistêmê), craftsmanship (technê), and practical wisdom (phronêsis) [9]. In particular, the practical wisdom component involves ethics and moral values which transcend scientific knowledge and technical skills. It is important to nurture engineering learners in all three intellectual dimensions [10]. As engineering knowledge is often enacted in response to societal problems [11] - [12], the engineering profession requires not only the mastery of knowledge and skills in science, mathematics, and technology but also a high ethical standard and a sense of social responsibility. This is echoed by perspectives in "sustainability competencies"; which intertwine with elements such as knowledge, skills, motives and affective dispositions that are crucial to advance sustainable development [13].

Three types of learning objectives for sustainability competencies were recommended by the UNESCO Education Sector [14]. They include cognitive, socio-emotional, and behavioral learning objectives that together equip students with not only the knowledge about the SDGs, but also the engagement as global citizens. Students, as global citizens, will ultimately be tasked with effecting the necessary socio-emotional and behavioral transformations for sustainable development and change to society. Sustainability competencies need to be acquired through action, experience, and reflection; they cannot be taught but are developed by the learners themselves [15].

\section{Engineering education for sustainable development and global citizenship: Early endeavors in Hong Kong}

Hong Kong is a major city and financial center the Asia Pacific. In the past century, it has undergone a rapid transformation from a small colonial outpost into a highly sophisticated regional financial hub. It is a westernized post-industrial region within the larger industrializing society of Greater China. 
A recent study in pre-university student engineering attitudes identified similarities between Hong Kong and other post-industrial societies; yet Hong Kong student engineering aspirations may be hindered by the lack of effective engineering curricula that connects technical knowledge to engineering efficacy in social and cultural contexts [16].

Early attempts in engineering education for sustainability competencies have been made in recent years. For example, Chan, Zhao, \& Luk surveyed a representative sample of 1,241 engineering undergraduates in Hong Kong to ascertain their views on holistic competencies, with insights regarding effective pedagogical approaches for holistic competencies development obtained [17]. Holistic competencies refer to holistic skills (in addition to that within the engineering domains), positive values, and attitudes, and share a coherent foundation with sustainability competencies (see [13], [14], and [17]).

Motivated by earlier attempts, together with the world-wide pressing need in engineering education for sustainable development, this implementation case study seeks to examine how engineering teachers may introduce elements of sustainability and global citizenship into course contexts. Our study is guided by the following research questions (RQs):

1. (RQ 1) How can the learning objectives for achieving the SDGs be introduced into an engineering course?

2. (RQ 2) How can the learning objectives for SDGs achievement be assessed within an engineering course?

3. (RQ 3) What are the pedagogical implications of this case study to engineering education for sustainable development and global citizenship?

\section{Methodology}

\section{Course Design}

Our implementation was conducted in the course "Social Media and Human Information Interaction" designed and taught by the first author, with three of the co-authors providing support as teaching assistants. The course is offered under the "Big Data: Systems and Applications" stream within the Information Engineering undergraduate curriculum at a research university in Hong Kong.

The aim of the course is to foster engineering student's multifaceted understanding of information, social media, and the study the cognitive processing of information by human and machines. It intends to motivate engineering students to critically reflect on the above topics, and to understand the impact of information engineering has in the development of solutions, and the important role played by information engineers in a global and societal context. Five learning outcomes are defined as achievements and are expected from students upon course completion. In particular, outcomes 3 to 5 were designed to promote sustainable development and global citizenship in learning: 
1. (Learning Outcome 1) gain conceptual knowledge and theoretical foundations in social media and human information interactions and be able to apply them in explaining various techno-societal phenomena.

2. (Learning Outcome 2) be able to analyze and interpret social media contents and social network structures.

3. (Learning Outcome 3) be able to understand their professional responsibility in sustainable development as information engineers.

4. (Learning Outcome 4) be able to understand the impact of information engineering solutions in a global and societal context.

5. (Learning Outcome 5) be able to stay abreast of contemporary issues and formulate professional recommendations and/or action plans based on human information behaviours.

The course spans 14 weeks and is focused on 4 topics (Table 1) which examine the technology and humanity dimensions of information and social media. It also introduces the theories, models, and analytic techniques related to social media and human information interaction (HII). In addition, the course also discusses how to integrate theories and concepts in social media and HII into the analytics and visualization of big data. In order to enable our students to recognize the relationship between global sustainable development goals and the subject knowledge, two topics have been introduced into the course, namely "Human Information-Interaction from a Global Citizenship Perspective" (Week 3) and "Big Data Visualization: Selected Cases from United Nations Statistics Division" (Week 13).

Table 1. Outline of the Course.

\begin{tabular}{|c|c|}
\hline $\begin{array}{l}\text { (Topic 1) Social } \\
\text { Media and HII: } \\
\text { An Overview }\end{array}$ & $\begin{array}{l}\text { Week 1. Introduction to Social Media and Human Information } \\
\text { Interaction } \\
\text { Week 2. Environments, Elements, and Information } \\
\text { Week 3. Human Information-Interaction from a Global Citizenship } \\
\text { Perspective }\end{array}$ \\
\hline $\begin{array}{l}\text { (Topic 2) } \\
\text { Information and } \\
\text { Human Cognition }\end{array}$ & $\begin{array}{l}\text { Week 4. Information and Human Cognition (Individual Dimension) } \\
\text { Week 5. Information and Human Cognition (Social Dimension) } \\
\text { Week 6. Physical Information } \\
\text { Week 7. Semantic Information } \\
\text { Week 8. Digital Information }\end{array}$ \\
\hline $\begin{array}{l}\text { (Topic 3) Social } \\
\text { Media Analytics }\end{array}$ & $\begin{array}{l}\text { Week 9. Social Media Analytics and Techniques (Natural Language } \\
\text { Processing) } \\
\text { Week 10. Social Media Analytics and Techniques (Sentiment Analysis) } \\
\text { Week 11. Social Media Analytics and Techniques (Social Network } \\
\text { Analysis) }\end{array}$ \\
\hline $\begin{array}{l}\text { (Topic 4) Big } \\
\text { Data } \\
\text { Visualization }\end{array}$ & $\begin{array}{l}\text { Week 12. Information Visualization } \\
\text { Week 13. Big Data Visualization: Selected Cases from United } \\
\text { Nations Statistics Division } \\
\text { Week 14. Course Wrap Up and Project Showcases }\end{array}$ \\
\hline
\end{tabular}


We adopted the assessment scheme presented in Table 2 below. A group project, "Social Media and Human Information Interaction for Sustainable Development", was included to develop student abilities in conceptualizing the subject content knowledge into professional recommendations for sustainable development from information engineering perspectives.

Table 2. Assessment Scheme of the Course.

\begin{tabular}{|l|l|l|}
\hline Assessment item & $\begin{array}{l}\text { Corresponding learning } \\
\text { outcomes }\end{array}$ & $\begin{array}{l}\text { Percentage (of } \\
\text { overall assessment) }\end{array}$ \\
\hline Interactive learning blogs & Learning outcome 1, 2 & $20 \%$ \\
\hline $\begin{array}{l}\text { Knowledge building community } \\
\text { participation }\end{array}$ & Learning outcomes 1, 2 & $20 \%$ \\
\hline $\begin{array}{l}\text { Group project 1: Social media and } \\
\text { HII for sustainable development }\end{array}$ & Learning outcomes 3, 4, 5 & $15 \%$ \\
\hline $\begin{array}{l}\text { Group project 2: Social media } \\
\text { analytics and information } \\
\text { visualization }\end{array}$ & Learning outcomes 1, 2 & $15 \%$ \\
\hline Final examination & Learning outcomes 1, 2, 3, 4, 5 & $30 \%$ \\
\hline
\end{tabular}

\section{Participants}

There were 68, third-year undergraduate student participants in this case study, conducted at a public research university in Hong Kong. They enrolled in and completed the course in Fall semester of 2017. The majority $(n=64)$ were from the Bachelor in Engineering in Information Engineering program (i.e. the program under which the course was offered), the remaining students were affiliated to the Computer Science $(n=2)$, Electronic Engineering $(n=1)$, and International Asian Studies $(n=1)$ programs, respectively. The students were formed into 16 project groups with size varying from 3 to 5 members.

\section{Data Collection and Analysis}

Students were required to work in teams to produce a policy report in which they; (1) identify an existing sustainability issue and name the SDGs involved; (2) analyze the issue and collect statistics from resources such as the UNSD (United Nations Statistics Division) statistical databases to support their argument; and (3) make policy solutions based on the knowledge learned from (or related to) the course. They needed to submit a project report that included three parts:

1. Part One: The Issue

2. Part Two: The Research

3. Part Three: Recommendations 
In Part One of the report, the groups were asked to identify one existing sustainability issue and specify:

- What is the issue?

- Where does it happen?

- Who are those suffering from this issue?

The groups were also asked to discuss the corresponding United Nations Sustainable Development Goals (SDGs) and target(s) related to the issue that had been identified.

To conduct Part Two, groups visited the databases and repositories hosted at United Nations Statistic Division (UNSD) [18] and identified the relevant dataset(s) that provided information on the issue they had identified in Part One. They were required to generate graphs, charts and/or tables from the data to support their arguments. Groups could use statistics and data available in other online resources and/or literature, provided that the references are properly cited.

Lastly, the groups were required to offer policy solutions and recommendations in Part Three of their report. Specifically, groups needed to apply the knowledge gained from the course, together with additional materials acquired from beyond lectures and course materials (such as websites and archives maintained by international organizations and collaborative communities, for example, the International Telecommunication Union (ITU) [19] and the United Nation Global Pulse [20]). Groups were required to make professional recommendations on how big data and social media analytics may be applied to solve or mitigate the issues that have been identified in Part One. Groups were also required to justify their recommendations using the principles from Human-Information Information as well as demonstrate understanding of the theoretical nature and properties of information.

We developed an analytic rubric (provided in the appendix) for assessment and provided it to students to guide their project work. The rubric included four dimensions; issue identification, research, policy solution, and overall report organization and was specified in four levels; exemplary, accomplished, developing, and beginning. We also interviewed individual students to learn and understand their views about their project experience.

\section{Results}

\section{Group Projects in Sustainable Development}

Student works were analyzed and evaluated according to the rubric provided in the appendix. A total number of 16 sustainability studies and policy reports were produced by the students at the end of the semester. Figure 1 shows samples of the policy reports. The captured report layouts were sourced from four different groups. They respectively illustrate (from left to right): identification of the issue and related SDGs, data visualization and statistics obtained from UN databases supporting student arguments on unsafe water, statistics supporting student arguments on issues in air pollution, and proposed solutions for preventing retail crime using thermographic cameras. The topics and their corresponding SDG(s) are listed in Table 3. 
Figure 1. Samples of policy reports submitted by the participating students. The groups worked on topics including (from left to right): urban-rural divide and social media affordances (SDG1, SDG4, and SDG13), water and sanitation for all with ICT and artificial intelligence (SDG6), leak access to safe water in Kenya (SGD3, SGD6, and SGD9), and preventing retail crime with ICT and social media (SDG 16).
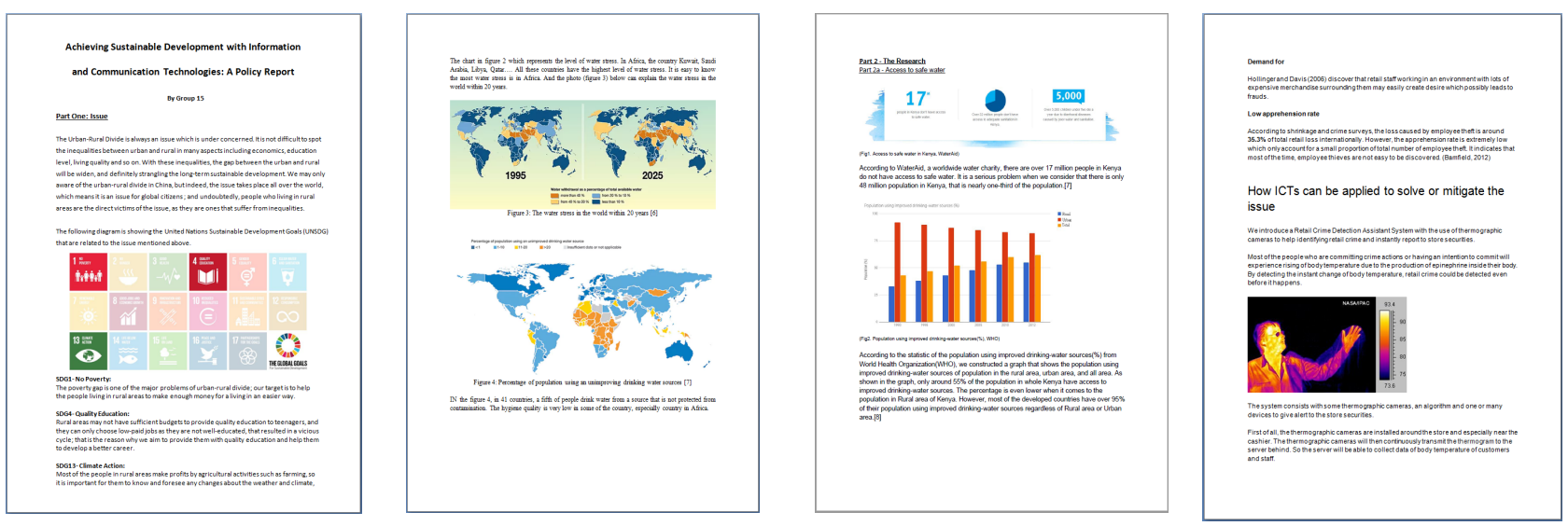

Table 3. Topics in Student Group Projects and SDGs Covered.

\begin{tabular}{|c|c|c|}
\hline & Topic & SDG(s) involved \\
\hline 1. & Emission: An enemy of modern world & $\begin{array}{l}\text { (SDG 3) Good Health and Well-being } \\
\text { and (SDG 13) Climate Action }\end{array}$ \\
\hline 2. & $\begin{array}{l}\text { Urban-rural divide and social media } \\
\text { affordances in market analysis, quality } \\
\text { education, and climate monitoring }\end{array}$ & $\begin{array}{l}\text { (SDG 1) No Poverty, (SDG 4) Quality } \\
\text { Education and (SDG 13) Climate Action }\end{array}$ \\
\hline 3. & $\begin{array}{l}\text { Wage inequality and the role of ICT in } \\
\text { quality education and ending poverty }\end{array}$ & $\begin{array}{l}\text { (SDG 1) No Poverty and (SDG 4) } \\
\text { Quality Education }\end{array}$ \\
\hline 4. & $\begin{array}{l}\text { Preventing retail crime with ICT and social } \\
\text { media }\end{array}$ & $\begin{array}{l}\text { (SDG 16) Peace, Justice and Strong } \\
\text { Institutions }\end{array}$ \\
\hline 5. & $\begin{array}{l}\text { Inequality in secondary education rates and } \\
\text { the achievement of quality education with } \\
\text { online education platforms }\end{array}$ & $\begin{array}{l}\text { (SDG 1) No Poverty and (SDG 4) } \\
\text { Quality Education }\end{array}$ \\
\hline 6. & Tackling food waste in Hong Kong by ICTs & $\begin{array}{l}\text { (SDG 6) Clean Water and Sanitation, } \\
\text { (SDG 7) Affordable and Clean Energy, } \\
\text { (SDG 13) Climate Action, (SDG 14) Life } \\
\text { below Water and (SDG 15) Life on Land. }\end{array}$ \\
\hline 7. & $\begin{array}{l}\text { Impediment of digital education in Hong } \\
\text { Kong }\end{array}$ & (SDG 4) Quality Education \\
\hline 8. & $\begin{array}{l}\text { Achieving sustainable production and } \\
\text { consumption in developing countries }\end{array}$ & $\begin{array}{l}\text { (SDG 12) Responsible Consumption and } \\
\text { Production, (SDG 13) Climate Action, } \\
\text { (SDG 14) Life below Water and (SDG } \\
\text { 15) Life on Land }\end{array}$ \\
\hline 9. & $\begin{array}{l}\text { Enhancing the Zero Hunger Challenge } \\
(\mathrm{ZHC}) \text { campaign by physical information } \\
\text { and social media }\end{array}$ & (SDG 2) Zero Hunger \\
\hline
\end{tabular}




\begin{tabular}{|c|l|l|}
\hline 10. & $\begin{array}{l}\text { Mitigating youth-unemployment with ICT } \\
\text { and social media }\end{array}$ & $\begin{array}{l}\text { (SDG 8) Decent Work and Economic } \\
\text { Growth and (SDG 9) Industry, } \\
\text { Innovation and Infrastructure }\end{array}$ \\
\hline 11. & $\begin{array}{l}\text { Ensuring access to water and sanitation for } \\
\text { all with ICT and artificial intelligence }\end{array}$ & (SDG 6) Clean Water and Sanitation \\
\hline 12. & $\begin{array}{l}\text { Promoting effective use of technology in } \\
\text { Hong Kong healthcare workers }\end{array}$ & (SDG 3) Good Health and Well-Being \\
\hline 13. & $\begin{array}{l}\text { On providing women and girls with equal } \\
\text { access to education, health care, and decent } \\
\text { work }\end{array}$ & (SDG 5) Gender Equality \\
\hline 14. & $\begin{array}{l}\text { On effective use of mobile communications } \\
\text { and ICT in quality education in developing } \\
\text { countries }\end{array}$ & (SDG 4) Quality Education \\
\hline 15. & $\begin{array}{l}\text { A charity mobile app for access to safe } \\
\text { water in Kenya }\end{array}$ & $\begin{array}{l}\text { (SDG 3) Good Health and Well-Being, } \\
\text { (SDG 6) Clean Water and Sanitation and } \\
\text { (SDG 9) Industry, Innovation and } \\
\text { Infrastructure }\end{array}$ \\
\hline 16. & $\begin{array}{l}\text { Sustainable broadcasting via social media } \\
\text { for } \mathrm{CO}_{2} \text { emission reduction }\end{array}$ & $\begin{array}{l}\text { (SDG 7) Affordable and Clean Energy } \\
\text { and (SDG 12) Responsible Consumption } \\
\text { and Production }\end{array}$ \\
\hline
\end{tabular}

\section{Student Views on Project Experience and Sustainable Development}

We interviewed student participants to learn about their project experience and their views regarding its effectiveness in promoting awareness of sustainable development and global citizenship. Below are excerpts from feedback provided by the some of the group assignment participants;

"[The] professor introduced the 17 Sustainable Development Goals of the United Nations to us and explained how ICT facilitates the achievement of the goals. I think the course has inspired me. It gave me a sense of belonging to a broader community, which beyond national boundaries. Now I am more aware of the role that engineer plays in the world and I will try to think of how to use engineering [knowledge and skills] to make the world better." (Participant 17)

"I agree that University students should have opportunities to expose themselves in a global perspective. Besides going out as an exchange student is an option, the chance of designing and determining policies which fosters UN SDGs is obviously a less demanding but effective option. It enables us to realize and understand what happens in other parts of the world, and we are free to give out our unique opinions to solve global issues using ICTs.... Besides studying fundamental engineering courses, it is also important for engineering students to develop a global sense. Things are happening at any time, and at anywhere. Something happens at a point of the planet may eventually affecting where we are standing. There are always inspirations and opportunities for us, so we should aware what is happening in the world." (Participant 51) 
However, one participant expressed their concern regarding the limitations of the project and expected a behavioral experience (to work on some actual projects) in addition to knowledge about the SDGs and document-based policy research:

"Talking about the global citizenship, I think knowing more about the topics and the UN SDGs are useful and may somehow provide insights about how technologies improve the wellbeing of people. However, knowing all these information from classes and online may not really arouse the interest of students. From my point of view, it would be meaningful and inspiring if we could really work on some projects on these topics or have industrial visits to companies focusing on the related subjects. Project 1 in general allows me to know more about what I can do with technology and make them useful to people, it is likely to be an informative project but not much motivation for me." (Participant 4)

\section{Discussions}

\section{Embedding learning objectives for SDGs into an engineering course}

(Research Question 1.) How can the learning objectives for achieving the SDGs be introduced into an engineering course?

In answering RQ1, we had included learning objectives for SDGs in the cognitive, socioemotional and behavioral domains in our course.

In order to implement the learning objective in the cognitive domain (which involves knowledge and thinking skills necessary for understanding the SDGs and the challenges in their achievement), we had included lectures on "Human Information-Interaction from a Global Citizenship Perspective" (Week 3) and "Big Data Visualization: Selected Cases from United Nations Statistics Division" (Week 13) (Table 1). The former introduced the ideas and concepts of sustainable development and global citizenship, examples of global challenges, the UN SDGs, and online resources and references. The latter introduced the UN Data API and visualization tools [21] (which are data access system to UN databases offered by the UNSD) and discussed a number of cases on big data visualization collected from the UNSD.

To implement the socio-emotional learning objective (which includes generic skills for students to collaborate and communicate and also the development of attitudes and motivations for sustainable development), the course provided a collaborative experience in policy research and recommendation. It also assisted participating students in improving understanding of their professional responsibilities in promoting sustainable development as information engineers, and to understand the impact of information engineering solutions in a global and societal context.

Lastly, by asking the students to formulate their findings and recommendations into policy reports which could potentially be submitted to corresponding institutions and organizations, they began to take behavioral actions by presenting their opinions, engineering knowledge, and engineering perspectives to global, multidisciplinary stakeholders. However, as expressed by one 
participant, students expected more opportunities to engage in a more direct way, such as taking part in the actual implementation of their recommended ideas, or to visit industrial parties that are involved in the SDGs implementation.

\section{Assessing learning objectives for SDGs in engineering course context}

(Research Question 2.) How can the learning objectives for SDGs achievement be assessed within an engineering course?

Assessment of learning objectives for sustainable development can be, and should be, conducted at multiple levels, varying from individual, class, program, institutional, large-scale national, and international levels [14]. While a few large-scale sustainability-related assessments such as the PISA International Civic and Citizenship Education Study (ICCS) [24] have been implemented, there have, until now, been only a limited number of course-level delivery of sustainabilityrelated learning objectives. RQ2 seeks effective assessment methods for SDGs achievement in an engineering course context. It is noted that teachers are powerful change facilitators. Assessment practices at course level can engage and empower the teachers to foster educational changes for towards sustainability.

As an early attempt in this implementation case, we introduced a group project in SDGs achievement (in terms of policy research), and developed an analytic rubric for assessment. The rubric was provided to the students to guide their project work. It included 4 dimensions: issue identification, research, policy solution, and organization and was specified in 4 levels: exemplary, accomplished, developing, and beginning. We evaluated student policy reports according to the rubric. The reports provided direct evidence [22] - [23] of engineering student learning for sustainable development. This not only served the purpose of learning performance evaluation, but also gave tangible and compelling indications of what participated students had learned.

\section{Pedagogical Implications}

(Research Question 3.) What are the pedagogical implications of this case study to engineering education for sustainable development and global citizenship?

The answer to RQ3 offers a number of pedagogical implications to engineering education for sustainable development and global citizenship. The current case study demonstrates how to employ collaborative projects and policy report development as pedagogical tools to integrate knowledge between SDGs and the engineering subject domain. It also facilitates the development of engineering student attitudes and competencies to response to global sustainability challenges. We attempted to implement UNESCO's roadmap and vision for education for sustainable development [25] by integrating sustainability principles into engineering education and learning settings.

Pedagogies for empowering and motivating the sense of sustainability and global citizenship in students should be those that can foster critical thinking as well as active engagement [14]. These include approaches that are learner-centered, action-oriented and transformative. In our case, we 
regarded our students as autonomous learners and facilitated an active development and integration of knowledge between engineering and sustainability. We took student knowledge and experiences in the social context into account and also engaged our students to reflect on their own learning process by including interactive learning blogs as an assessment item [Table 2]). Although we were constrained by course-level factors such as time and the scope of student projects, we were able to engage our students in action-oriented experiential learning [26] by asking them to develop policy recommendations for sustainable development based on their engineering subject domain knowledge.

As one participant noted, the course project experience was "less demanding but effective" and provided them with opportunities to "give out [their] opinions to solve global issues with ICTs". Lastly, we illustrated how transformative learning could be introduced within an engineering course. Transformative learning aims at empowering learners to "question and change the ways they see and think about the world in order to deepen their understanding of it" [14], [27] - [28]. We were encouraged to learn from participant feedback that the project had inspired them by giving them "a sense of belonging to a broader community, which beyond national boundaries" and become "more aware of the role that engineer plays in the world", and "try to think of how to use engineering [knowledge and skills] to make the world better".

Our course-level case study demonstrates how to effectively implement action-oriented transformative learning given the constraints of time and scope within a course. It should be remarked that other learning experiences and activities, such as community outreach or capstone project experiences can also be introduced in order to further reinforce student learning for the SDGs and global citizenship.

\section{Conclusion}

Engineers are vital stakeholders in the achievement of sustainable development, as they are in the important position to act responsibly for the environment, economy, and society for present and future generations. Engineering educators are at the important position to motivate engineering students to develop the sense of global citizenship, to critically reflect on the role played by themselves (as engineers of the future) in sustainable development, and to reflectively relate the SDGs to their own subject knowledge learning. In the current work, we have described and discussed how to introduce elements of sustainable development and global citizenship into a regular undergraduate course within the engineering curriculum. We have suggested a project work related to SDGs achievement and provided its assessment rubrics. We have collected direct evidence of learning from our engineering undergraduate participants and discussed the pedagogical implications of our implementation. We hope our work can engender further implementations and discussions on engineering education for sustainable development.

\section{Acknowledgement}

This work was supported in part by the University Grants Committee under Funding Scheme for Teaching and Learning Related Proposals (2016-19 Triennium) [grant number HKU9/T\&L/1619]. The authors would like to thank Stephen Cheng for his valuable advice on the manuscript. 


\section{References}

[1] World Economic Forum, The Global Risks Report 2016, 2016. [Online]. Available: http://www3.weforum.org/docs/Media/TheGlobalRisksReport2016.pdf [Accessed: 31-Jan2018]

[2] United Nations, Transforming our world: the 2030 Agenda for Sustainable Development, 2015. [Online]. Available:

https://sustainabledevelopment.un.org/post2015/transformingourworld. [Accessed: 27-Jan2018].

[3] E. W. Colglazier, "The United Nations Sustanable Development Goals: What Can Engineering and Engineering Technology Educators Do?" Distinguished Lecture, ASEE Annual Conference. 2017.

[4] World Commission on Environment and Development (WCED), Our Common Future. Oxford, England: Oxford University Press, 1987.

[5] W.E Kelly, Brieffor GSDR - 2016 Update: Engineering Education for Sustainable Development, 2016. [Online]. Available:

https://sustainabledevelopment.un.org/content/documents/970027_Kelly_Engineering \%20Education\%20for\%20Sustainable\%20Development.pdf. [Accessed: 28-Jan-2018]

[6] Byrne et al., "Engineering education for sustainable development: A review of international progress", 2010. [Online]. Available: https://cora.ucc.ie/handle/10468/372 [Accessed: 31-Jan-2018].

[7] K. H. Al-Rawahy, "Engineering education and sustainable development: the missing link", Social and Behavioral Sciences, vol. 102, pp. 392 - 401, 2013.

[8] Aristotle. Nicomachean Ethics, second edition, translated by Terence Irwin, IN: Indianapolis, Hackett Publishing, 1999.

[9] H. J. Curzer, Aristotle and the virtues. Oxford, UK: Oxford University Press, 2012.

[10] R. Y.-Y. Chan and C. K. Y. Chan, "Nurturing virtuous minds in gifted engineering learners", in Teaching Gifted Learners in STEM Subjects: Developing Talent in Science, Technology, Engineering and Mathematics, K. S. Taber, M. Sumida, and L. McClure, L., Eds., Abingdon, Oxon, UK: Routledge, 2018, pp. 186 - 197.

[11] S. L. Goldman, "Why we need a philosophy of engineering: A work in progress", Interdisciplinary Science Reviews, vol. 29, no. 2, pp. 163-176, 2004.

[12] D. Montfort, S. Brown, and D. Shinew, "The personal epistemologies of civil engineering faculty", Journal of Engineering Education, vol. 103, no. 3, pp. 388-416, 2014.

[13] A. Wiek, L. Withycombe, and C. L. Redman, "Key competencies in sustainability: a reference framework for academic program development," Sustainability Science, vol. 6, no. 2, pp. 203-218, 2011.

[14] United Nations Educational, Scientific and Cultural Organization (UNESCO), Education for Sustainable Development Goals: Learning Objectives, 2017.

[15] United Nations Educational, Scientific and Cultural Organization (UNESCO), Thematic Indicators to Monitor the Education 2030 Agenda, Technical Advisory Group Proposal, 2015.

[16] P. Kutnick, R. Y. -Y. Chan, C. K. Y. Chan, D. Good, B. P. -Y. Lee, and V. K. W. Lai, "Aspiring to become an engineer in Hong Kong: Effects of engineering education and demographic background on secondary students' expectation to become an engineer", European Journal of Engineering Education, 2018 (in print). 
[17] C. K. Y. Chan, Y. Zhao, and L. Y. Y. Luk, "A validated and reliable instrument investigating engineering students' perceptions of competency in generic skills", Journal of Engineering Education, vol. 106, no. 2, pp. 299-325, 2017.

[18] United Nations Statistics Division [Online]. Available: https:/unstats.un.org/home/. [Accessed: 28-Jan-2018]

[19] International Telecommunication Union, "ICTs for a Sustainable World \#ICT4SDG", 2018. [Online]. Available: https://www.itu.int/en/sustainable-world [Accessed: 28-Jan-2018]

[20] United Nations Global Pulse, "Harnessing Big Data for Development and Humanitarian Action", 2018. [Online] Available: https://www.unglobalpulse.org [Accessed: 28-Jan-2018]

[21] UNdata [Online]. Available: http://data.un.org [Accessed: 5-Feb-2018]

[22] L. Suskie, Assessing Student Learning: A Common Sense Guide, 2nd ed., Jossey-Bass, CA: San Francisco, 2009.

[23] W. T. Banta and C. A. Palomba, Assessment Essentials: Planning, Implementing, and Improving Assessment in Higher Education, 2nd ed. San Francisco, CA: Jossey-Bass, 2015.

[24] W. Schulz, J. Ainley, J., Fraillon, D. Kerr, and B. Losito, ICCS 2009 International Report: Civic knowledge, attitudes, and engagement among lower-secondary school students in 38 countries. Amsterdam, International Association for the Evaluation of Educational Achievement, 2009.

[25] UNESCO, "UNESCO Roadmap for Implementing the Global Action Programme on Education for Sustainable Development", 2014. [Online] Available: http://unesdoc.unesco.org/images/0023/002305/230514e.pdf [Accessed: 5-Feb-2018]

[26] D. A. Kolb, Experiential Learning: Experience as the Source of Learning and Development, Englewood Cliffs, N.J., Prentice-Hall, 1984.

[27] J. Mezirow, Learning as Transformation: Critical Perspectives on a Theory in Progress. San Francisco, Jossey-Bass, 2000.

[28] G. M. Slavich P. G. Zimbardo, "Transformational teaching: Theoretical underpinnings, basic principles, and core methods", Educational Psychology Review, vol. 24, no. 4, pp. 569-608, 2012. 


\section{Appendix}

Table A.1. Evaluation Rubric for the Group Project

\begin{tabular}{|c|c|c|c|c|}
\hline & Exemplary & Accomplished & Developing & Beginning \\
\hline $\begin{array}{l}\text { Identification } \\
\text { of Issue }\end{array}$ & $\begin{array}{l}\text { Issue and } \\
\text { multiple relevant } \\
\text { SGDs and targets } \\
\text { identified. Be } \\
\text { able to explain } \\
\text { the relationship } \\
\text { between the issue } \\
\text { and the SDGs. }\end{array}$ & $\begin{array}{l}\text { Issue and } \\
\text { multiple relevant } \\
\text { SGDs and targets } \\
\text { identified. }\end{array}$ & $\begin{array}{l}\text { Issue and one } \\
\text { relevant SGD } \\
\text { identified. }\end{array}$ & $\begin{array}{l}\text { Issue identified } \\
\text { without } \\
\text { mentioning the } \\
\text { relevant SDGs. }\end{array}$ \\
\hline The Research & $\begin{array}{l}\text { Relevant } \\
\text { statistics } \\
\text { obtained from } \\
\text { the UNSD } \\
\text { databases as well } \\
\text { as other sources } \\
\text { are presented to } \\
\text { support the issue } \\
\text { identification. }\end{array}$ & $\begin{array}{l}\text { Relevant } \\
\text { statistics } \\
\text { obtained from } \\
\text { the UNSD } \\
\text { databases are } \\
\text { presented to } \\
\text { support the issue } \\
\text { identification. }\end{array}$ & $\begin{array}{l}\text { Relevant } \\
\text { statistics } \\
\text { obtained from } \\
\text { other sources are } \\
\text { presented to } \\
\text { support the issue } \\
\text { identification. }\end{array}$ & $\begin{array}{l}\text { Very limited } \\
\text { statistics are } \\
\text { included to } \\
\text { support the issue } \\
\text { identification. }\end{array}$ \\
\hline $\begin{array}{l}\text { Policy Solution } \\
\text { and Re- } \\
\text { commendation }\end{array}$ & $\begin{array}{l}\text { Policy solution is } \\
\text { well-developed } \\
\text { and is supported } \\
\text { by an excellent } \\
\text { understanding of } \\
\text { social media } \\
\text { and/or HII } \\
\text { principles; } \\
\text { argument is } \\
\text { logical and with } \\
\text { the support of the } \\
\text { statistics } \\
\text { presented in Part } \\
\text { Two. } \\
\text { Recommendation } \\
\text { on several } \\
\text { relevant aspects } \\
\text { is made; and is } \\
\text { integrated into an } \\
\text { innovative } \\
\text { suggested } \\
\text { solution. }\end{array}$ & $\begin{array}{l}\text { Policy solution is } \\
\text { tentatively } \\
\text { asserted and is } \\
\text { supported by an } \\
\text { understanding of } \\
\text { social media } \\
\text { and/or HII } \\
\text { principles; } \\
\text { argument is } \\
\text { sound and } \\
\text { partially } \\
\text { supported by the } \\
\text { statistics } \\
\text { presented in Part } \\
\text { Two. } \\
\text { Recommendation } \\
\text { on several } \\
\text { relevant } \\
\text { independent } \\
\text { aspects is made. }\end{array}$ & $\begin{array}{l}\text { Policy solution is } \\
\text { made with a } \\
\text { basic } \\
\text { understanding of } \\
\text { social media } \\
\text { and/or HII; } \\
\text { argument is } \\
\text { presented } \\
\text { without the } \\
\text { support of any } \\
\text { statistics. } \\
\text { Recommendation } \\
\text { on one relevant } \\
\text { aspect is made. }\end{array}$ & $\begin{array}{l}\text { Policy solution is } \\
\text { very basic and is } \\
\text { not based in an } \\
\text { understanding of } \\
\text { social media } \\
\text { and/or HII; } \\
\text { argument is } \\
\text { presented } \\
\text { without the } \\
\text { support of any } \\
\text { statistics. } \\
\text { A very early } \\
\text { attempt to } \\
\text { provide a } \\
\text { recommendation. }\end{array}$ \\
\hline
\end{tabular}




\begin{tabular}{|c|c|c|c|c|}
\hline $\begin{array}{l}\text { Policy Report } \\
\text { Organization }\end{array}$ & $\begin{array}{l}\text { A coherent and } \\
\text { unifying theme is } \\
\text { established and } \\
\text { maintained } \\
\text { throughout the } \\
\text { entire policy } \\
\text { report. Clear } \\
\text { internal divisions } \\
\text { (e.g., Part One, } \\
\text { Part Two, and } \\
\text { Part Three, and } \\
\text { references) are } \\
\text { created. Sections } \\
\text { headings (and } \\
\text { subheadings) are } \\
\text { marked clearly. } \\
\text { Relevant } \\
\text { visualizations, } \\
\text { figures, tables, } \\
\text { and references } \\
\text { are given in the } \\
\text { report. }\end{array}$ & $\begin{array}{l}\text { Effort in } \\
\text { establishing a } \\
\text { coherent and } \\
\text { unifying theme } \\
\text { throughout the } \\
\text { report is shown. } \\
\text { Clear internal } \\
\text { divisions (e.g., } \\
\text { Part One, Part } \\
\text { Two, and Part } \\
\text { Three, and } \\
\text { references) are } \\
\text { created. Sections } \\
\text { headings (and } \\
\text { subheadings) are } \\
\text { marked clearly. } \\
\text { Some } \\
\text { visualizations, } \\
\text { figures, tables, } \\
\text { and references } \\
\text { are given in the } \\
\text { report. }\end{array}$ & $\begin{array}{l}\text { Report } \\
\text { organization is } \\
\text { somewhat } \\
\text { mechanical. } \\
\text { Essential } \\
\text { elements of the } \\
\text { report (e.g., Part } \\
\text { One, Part Two, } \\
\text { and Part Three, } \\
\text { and references) } \\
\text { are present but } \\
\text { without a clear } \\
\text { internal } \\
\text { divisions. } \\
\text { Sections } \\
\text { headings (and } \\
\text { subheadings) are } \\
\text { present but does } \\
\text { not enhance } \\
\text { readability. } \\
\text { Figures, tables, } \\
\text { and references } \\
\text { are barely } \\
\text { included in the } \\
\text { report. }\end{array}$ & $\begin{array}{l}\text { Lack of } \\
\text { organization. } \\
\text { Some of the } \\
\text { essential } \\
\text { elements of the } \\
\text { report are absent. } \\
\text { Internal } \\
\text { divisions are } \\
\text { unclear. No } \\
\text { figures, tables, } \\
\text { and references } \\
\text { are included in } \\
\text { the report. }\end{array}$ \\
\hline
\end{tabular}

